\title{
Machinability of hypereutectic cast Al-Si alloys processed by SSM processing technique
}

\author{
P K SOOD $^{1, *}$, RAKESH SEHGAL ${ }^{1}$ and D K DWIVEDI ${ }^{2}$ \\ ${ }^{1}$ Department of Mechanical Engineering, National Institute of Technology, Hamirpur 177005, India \\ ${ }^{2}$ Department of Mechanical and Industrial Engineering, Indian Institute of Technology, Roorkee 247667, India \\ e-mail: pks@ nith.ac.in
}

MS received 28 July 2015; revised 16 March 2016; accepted 11 November 2016

\begin{abstract}
Experimental investigation carried out on the machinability studies to determine the influence of semi-solid metal processing and modification on hypereutectic $\mathrm{Al}-20 \mathrm{Si}-0.5 \mathrm{Mg}-1.2 \mathrm{Fe}$-based alloy produced by conventional cast and semi-solid metal processing technique (mechanical stirring) and modified with iron correctors ( $\mathrm{Be}$ and $\mathrm{Cd}$ ) has been presented in this paper. The alloys under investigation were prepared by controlling melt using an induction melting furnace. Stirring of semi-solid metal takes place at constant cooling conditions from liquidus temperature at a constant stirring speed of $400 \mathrm{rpm}$. To determine the machining performance characteristics an orthogonal array, signal-to-noise ratio and statistical tool analysis of variance were jointly used during experimentation. A CNC lathe was used to conduct experiments in dry condition and coated carbide inserts were used as tool inserts. Machining variables like cutting velocity, approaching angle, feed rate and depth of cut, which can be considered as process parameters, are taken into account. The combined effect of modification and semi-solid metal processing has a significant effect on the machining characteristics, which was concluded from study. The modified alloy processed by semi-solid metal processing technique exhibits better machinability conditions when compared with the conventional cast. The feed rate has more effect on machining behaviour.
\end{abstract}

Keywords. Machinability; hypereutectic Al-Si alloy; Taguchi method; analysis of variance; beryllium and cadmium; CNC turning centre.

\section{Introduction}

Hypereutectic aluminium-silicon alloys have wide range of excellent mechanical and thermal properties due to which they are well-known, used materials for manufacturing parts of automobile, aircraft and electronic equipment. They are extensively used for engine parts (propeller casing) and air compressor cylinder and machining, which are generally required in producing automobile parts (rims, disc brakes, etc.). Hypereutectic aluminium-silicon alloys are said to be the most difficult to machine among the various aluminium alloys as the occurrence of prime coarse crystal-free silicon causes rapid tool wear because of their hardness. Brittle intermetallic phases deteriorate the mechanical properties of $\mathrm{Al}-\mathrm{Si}$ alloy, which are generally formed by combining iron into aluminium and silicon (mostly iron is present in little quantity in aluminium alloy). Out of these intermetallic phases observed in aluminium alloy it is generally expected that plate-type shapes are the most harmful to mechanical properties (e.g., elongation). Changing the shape of intermetallic phases from plate type

*For correspondence to Chinese script will improve the properties and structure of hypereutectic $\mathrm{Al}-\mathrm{Si}$ alloy.

Many investigators tried to improve the machinability of alloys by adding special alloying elements and behaviour of primary silicon particles by controlling the solidification to acquire the desired properties [1-3]. It was reported by Liebermann that cooling rate during solidification affects the primary Si particle. Finer structure can be obtained by spray casting, melt spinning and by semi-solid metal processing. The semi-solid metal processing (mechanical stirring) is one of the tools for enhancement of localized surface properties. It increases the ductility and strength and also improves the surface properties during machining operation. Beryllium and cadmium (iron correctors) are added generally to improve the machinability [4,5]. For higher production rates, machines with higher degree of automation are to be used. The most significant are NC/CNC machine tools, which have been provided with higher power, greater spindle speed, spindle accuracy, better control systems and wide range of speeds and feeds [6]. Economy in various applications is generally obtained by analysing machinability of material and varies according to the requirements. The magnitude of cutting force components acting on the tool, power 
consumed, surface quality and chip form produced under specified conditions are some of the criteria that are commonly used according to requirements for evaluation of machinability [7, 8]. Cutting forces are generally affected by machining variables and other factors like un-deformed chip thickness and properties of cutting tool material, type of tool wear and geometry of tool [9]. There are two sources of power consumption in CNC machine tools: peripheral devices, i.e., spindle, servo motor and linear motor. The first is considered as constant power consumed during idle time and is constant over the time the machine is turned on. The second ones are machining variables, which affect the power consumption. As compared with conventional machining on a simple lathe it is necessary to operate $\mathrm{CNC}$ machines economically and efficiently because of high cost of CNC machines tools [10]. Machining of metals means the removal of extra material from the metal by the process like facing and turning. The material is removed from the workpiece in the form of chips. Nature of chips depends upon the operation, properties of work material and cutting conditions. The chips are produced by localized shearing, which takes place between the tool and workpiece point of contact over a very narrow region called shear plane or shear zone. Detrimental effect on surface finish is caused by chip shape and various sizes of widely undesirable chip formation. To study the machining behaviour the types of chips formed are of importance in machining $[11,12]$. Geometry of the tool insert and substrate coating has direct influence on the performance of coated tool and hence enhances the tool life because of high hardness, wear resistance and chemical stability of these coatings [13]. For robust design the Taguchi parameter design is an important one and offers a systematic approach to optimize design. Signal to noise ratio measures quality with emphasis on variation and orthogonal array and accommodates many design factors simultaneously, for which two major tools are used [14]. The higher iron content in an $\mathrm{Al}-12 \mathrm{Si}-\mathrm{Cu}-\mathrm{Mg}$ alloy that contains coarser iron-rich $\beta$ phase intermetallic compounds results in more quantity than in low iron content alloy [15]. Joining of Al-based MMCs was reported and suitable joining techniques and processes involved are defined [16]. A hypereutectic Al-Si alloy that turns with CVD diamond-coated $\mathrm{Si}_{4} \mathrm{~N}_{4}$ tool inserts was investigated in order to study its machining behaviour and to carry out machining, diamond tools of complex geometry are used due to their good mechanical properties [17].

In the current investigation an attempt has been made to carry out the refinement and modifications of micro-constituents of alloys before casting, which in turn changes the microstructure, improves the mechanical properties and also affects the machinability. The aim of this investigation is to study the effects of cutting variables along with geometry and orientation of tool insert on machining behaviour and chip formation during CNC turning of developed hypereutectic aluminium-silicon alloys with and without iron correctors (beryllium and cadmium) and the secondary objective is to optimize the machining process.

\section{Experimental work}

This section deals with preparation of experimental hypereutectic aluminium-silicon alloys and microscopy; machinability tests performed have been discussed.

\subsection{Materials}

The experimental alloy (Al-20Si-0.5Mg-1.2Fe) was prepared by melting of master alloys $\mathrm{Al}-30 \% \mathrm{Si}, \mathrm{Al}-10 \% \mathrm{Mg}$ and $\mathrm{Al}-10 \% \mathrm{Fe}$ in suitable quantities with $99.99 \%$ of aluminium in a graphite crucible using an induction furnace. To avoid oxidation the melt was covered with flux. Hexachloro-ethane was used for the degassing. The molten alloy was cast in a metallic mould $(37 \mathrm{~mm} \times 150 \mathrm{~mm})$ after proper mixing to make samples for machining by a conventional casting through stir cast technique. Inclusions and dross particles if found were trapped by a filter, which was kept at the top. Stir casting was performed at $800^{\circ} \mathrm{C}$ using a stirrer rotating at a constant speed of $400 \mathrm{rpm}$ for a period of $120 \mathrm{~s}$. Beryllium and cadmium (0.03 wt.\%) were added into the molten alloys in elemental form followed by conventional and stir casting. The nominal composition of alloys prepared is shown in table 1; the induction furnace used for the purpose is shown in figure 1. The mechanical properties of developed alloy are presented in table 2.

\subsection{Metallographic observation}

Microstructural evaluation studies were carried out on the alloys developed to investigate the morphological changes in the phases due to stirring and modification by the iron correctors (beryllium and cadmium), using a scanning electron microscope, and its impact on the machinability.

\subsection{Machining experiments}

A high-precision CNC turning centre Sprit 16 TC equipped with a Siemens control system having two simultaneously controlled axes, namely, $Z$-axis, movement of carriage parallel to spindle axis (longitudinal), and $X$-axis, movement of turret slide at right angle to spindle axis (cross),

Table 1. Nominal composition of Al-Si alloys (element-wt.\%).

\begin{tabular}{lcccccc}
\hline & & \multicolumn{5}{c}{ Elements } \\
\cline { 3 - 7 } S1. no. & Composition & $\mathrm{Si}$ & $\mathrm{Mg}$ & $\mathrm{Fe}$ & $\mathrm{Be}$ & $\mathrm{Cd}$ \\
\hline 1 & Alloy 1 Conventional cast & 20 & 0.50 & 1.2 & - & - \\
2 & Alloy 2 Stir cast & 20 & 0.50 & 1.2 & - & - \\
3 & Alloy 3 Conventional cast & 20 & 0.50 & 1.2 & 0.03 & - \\
4 & Alloy 4 Stir cast & 20 & 0.50 & 1.2 & 0.03 & - \\
5 & Alloy 5 Conventional cast & 20 & 0.50 & 1.2 & - & 0.03 \\
6 & Alloy 6 Stir cast & 20 & 0.50 & 1.2 & - & 0.03 \\
\hline
\end{tabular}




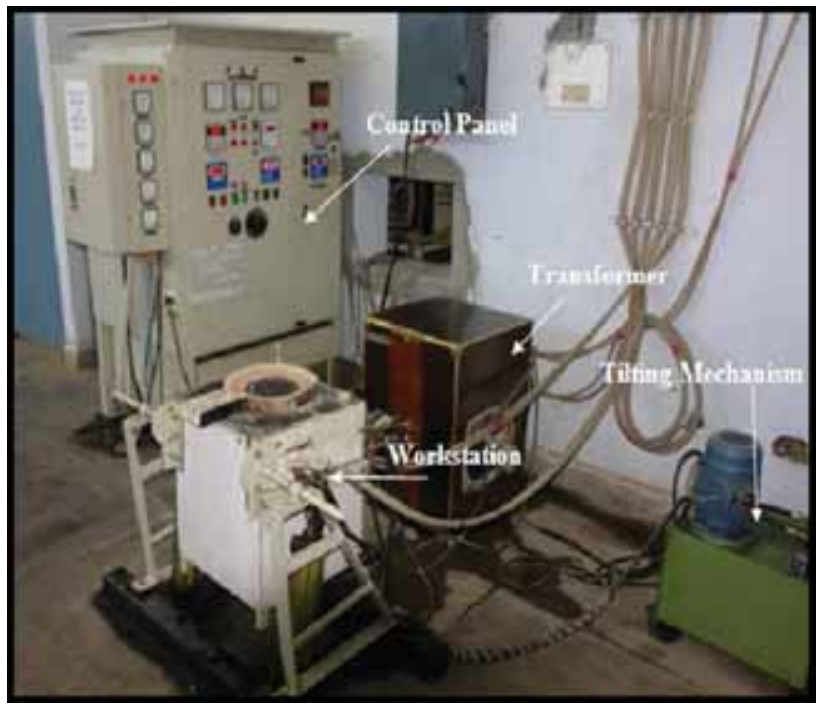

Figure 1. Induction melting furnace.

both these axes can be traversed in rapid feed and jog mode, was used for turning the alloys developed. Coated carbide inserts (CCMT09304) and a CVD multilayer coated, cobalt-enriched substrate manufactured by WIDIA were used for machining. The machining process was carried out without using a coolant or any lubricant (i.e., dry turning) and sample length of $20 \mathrm{~mm}$ was kept for each experiment during investigation. The machining parameters fixed for investigation are shown in table 3 . These parameters were selected based upon the literature survey and capability of tool insert used for machining. Four factors were considered and for each factor four levels were chosen for conducting experiments. Figure 2 shows an experimental setup having three-component turning dynamometer (TeLC with DKM 2010 software), which was used for evaluation of the main cutting force $(\mathrm{Fc})$ and power consumption. The response parameters like main cutting force, feed force and passive components of forces were measured with the help of the dynamometer, which was equipped with three load cells bolted rigidly on the tool turret. Study of chip analysis was carried out by considering the size of chip using number of chips per gramme criteria, and variation in number of chips per gramme has been observed. The chip shape was reported in the form of photographs using a conventional camera. To assess the surface roughness for investigation the arithmetic average $\left(R_{\mathrm{a}}\right)$ parameter was used. A surface roughness tester of Mitutoyo make (model no. SJ 301) was used to measure the surface roughness of machined surface after each experiment.

\subsection{Optimization}

Effect of four machining process parameters, i.e., cutting speed, feed rate, depth of cut and approaching angle, on machining process was observed using the Taguchi method, on which the design of experiment was based as per investigation plan. MINTAB software was used to analyse the results. Optimized cutting parameters for machining characteristics are obtained based on the results. To confirm the effectiveness of the approach among the three categories of quality characteristics, i.e., lower the better, higher the better and nominal the better, signal-to-noise ratio $(S / N)$ was used for design optimization in order to examine the experimental results. Lower the better characteristic, adapted for the present study to evaluate machining characteristics, has been taken into consideration. Next, ANOVA analysis was used to check the significance of each parameter. The parameter levels for the experiments are shown in table 4 .

Table 2. Mechanical properties of alloys (element-wt.\%).

\begin{tabular}{lcccccc}
\hline Mechanical properties & Alloy 1 & Alloy 2 & Alloy 3 & Alloy 4 & Alloy 5 & Alloy 6 \\
\hline Tensile strength (MPA) & 160 & 171 & 170 & 187 & 174 \\
Hardness (HRB) & 82 & 76 & 78 & 70 & 79 & 71 \\
Elongation (\%) & 1.2 & 2.3 & 1.8 & 2.9 & 2.0 & 2.9 \\
\hline
\end{tabular}

Table 3. Cutting parameters used for machinability study.

\begin{tabular}{|c|c|c|c|c|c|c|}
\hline Symbol & Cutting parameter & Unit & Level 1 & Level 2 & Level 3 & Level 4 \\
\hline A & Cutting speed & $\mathrm{m} / \mathrm{min}$ & 100 & 125 & 150 & 175 \\
\hline $\mathrm{B}$ & Feed rate & $\mathrm{mm} / \mathrm{rev}$ & 0.1 & 0.2 & 0.3 & 0.4 \\
\hline $\mathrm{C}$ & Depth of cut & $\mathrm{mm}$ & 1.0 & 1.5 & 2.0 & 2.5 \\
\hline $\mathrm{D}$ & Approaching angle & $\operatorname{deg}$ & 45 & 60 & 75 & 90 \\
\hline
\end{tabular}




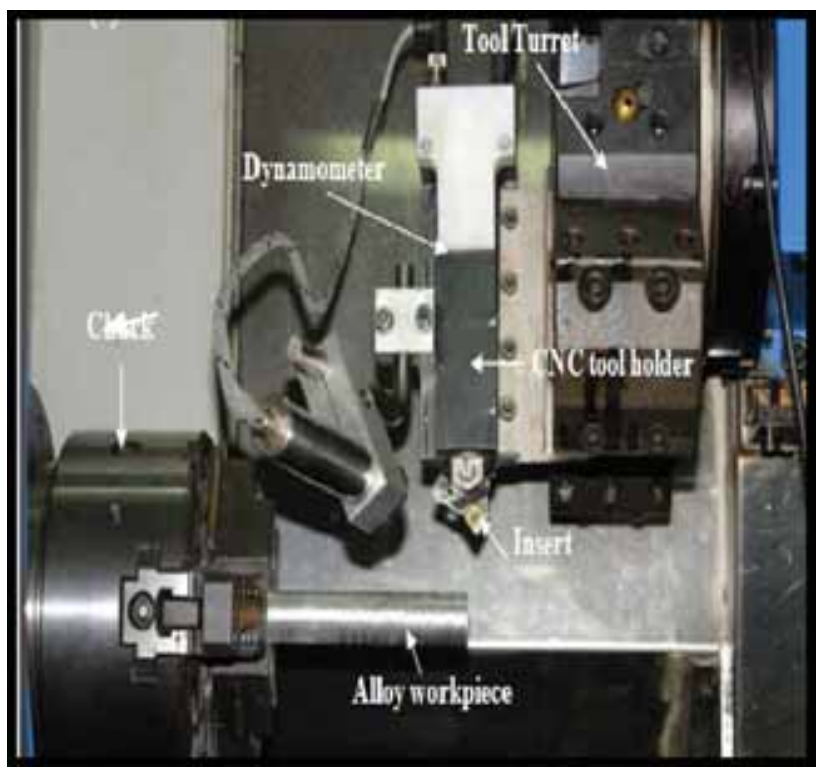

Figure 2. Experimental set-up.

Table 4. Experimental designs for using $\mathrm{L}_{16}$ orthogonal array.

\begin{tabular}{lcccc}
\hline $\begin{array}{l}\text { Experiment } \\
\text { no. }\end{array}$ & $\begin{array}{c}\text { Cutting } \\
\text { speed } \\
(\mathrm{m} / \mathrm{min})\end{array}$ & $\begin{array}{c}\text { Feed rate } \\
(\mathrm{mm} / \mathrm{rev})\end{array}$ & $\begin{array}{c}\text { Depth of } \\
\text { cut }(\mathrm{mm})\end{array}$ & $\begin{array}{c}\text { Approaching } \\
\text { angle }\left(^{\circ}\right)\end{array}$ \\
\hline 1 & 100 & 0.1 & 1.0 & 45 \\
2 & 100 & 0.2 & 1.5 & 60 \\
3 & 100 & 0.3 & 2.0 & 75 \\
4 & 100 & 0.4 & 2.5 & 90 \\
5 & 125 & 0.1 & 1.5 & 75 \\
6 & 125 & 0.2 & 1.0 & 90 \\
7 & 125 & 0.3 & 2.5 & 45 \\
8 & 125 & 0.4 & 2.0 & 60 \\
9 & 150 & 0.1 & 2.0 & 90 \\
10 & 150 & 0.2 & 2.5 & 75 \\
11 & 150 & 0.3 & 1.0 & 60 \\
12 & 150 & 0.4 & 1.5 & 45 \\
13 & 175 & 0.1 & 2.5 & 60 \\
14 & 175 & 0.2 & 2.0 & 45 \\
15 & 175 & 0.3 & 1.5 & 90 \\
16 & 175 & 0.4 & 1.0 & 75 \\
\hline
\end{tabular}

\section{Results and analysis}

The following sub-sections explain the experimental results obtained in the present study, which are analysed and discussed.

\subsection{Microstructural evaluations}

Microstructure of cast hypereutectic alloy without iron corrector is shown in figure $3 \mathrm{a}$. It can be observed that large cubed primary silicon particles along with needle shape $\beta$ - phase intermetallic are primarily present in the microstructure. The effect of semi-solid metal processing of unmodified and $\mathrm{Cd}$-modified hypereutectic alloy system on the microstructure is shown in figure $3 \mathrm{~b}$. From the microstructure it can be observed that semi-solid metal processing of Cd-modified alloy system almost eliminates the harmful $\beta$-phase needle shape intermetallic compounds from the microstructure. It is expected that these variations in the microstructure of the alloy due to $\mathrm{Cd} / \mathrm{Be}$ modification and semi-solid processing will affect the machinability.

\subsection{Machining results}

With respect to response parameters the machining behaviour of $\mathrm{Al}-\mathrm{Si}$ alloys is studied using an $\mathrm{L}_{16}$ orthogonal array experimental design. Figure 4 illustrates the details of schematic approach followed for the evaluation of machining parameters as per experimental plan.

\subsection{Cutting forces}

An orthogonal array was used to reduce the number of experiments for determining the optimal cutting parameters, for which the Taguchi-method-based DOE was used for hypereutectic aluminium-silicon alloys developed in the present study. The result for machining performance of the alloy developed is shown in table 5.

The effect of each control factor is observed through response table/response graphs. The response graphs for all control factors are shown in figure 5a-f. To identify the machining parameters that are statistically significant for cutting force $(\mathrm{Fc})$, statistical analysis of variance (ANOVA) is performed. The results of ANOVA are shown in tables 7-12. Response graph 6a for alloy-1 indicates that the feed rate and depth of cut have more influence than cutting speed and approaching angle, in light of their delta value. Based on the response graph, it can be noted that during turning of alloy 1 , the minimum cutting forces are generated on the cutting tool for $150 \mathrm{~m} / \mathrm{min}$ cutting speed, $0.2 \mathrm{~mm} / \mathrm{rev}$ feed rate, $1.0 \mathrm{~mm}$ depth of cut and $60^{\circ}$ approaching angle. In the same manner, $S / N$ ratio analysis was completed to show the influence of cutting parameters on main cutting force during the machining of alloy 2-6. It was found that in case of alloys 2-4, feed rate and depth of cut have more effect on cutting force than cutting speed and approaching angle, while in the case of alloys 5 and 6 , feed rate and cutting speed have more effect on cutting force than approaching angle and depth of cut.

With increase in cutting force, feed rate also increases during the machining of alloy 1-6 in all conditions. Cutting force in turning operation can be computed as a product of specific cutting pressure and uncut chip cross-section. Specific pressure is the cutting force per unit area of un-deformed chip cross-section. The specific cutting 

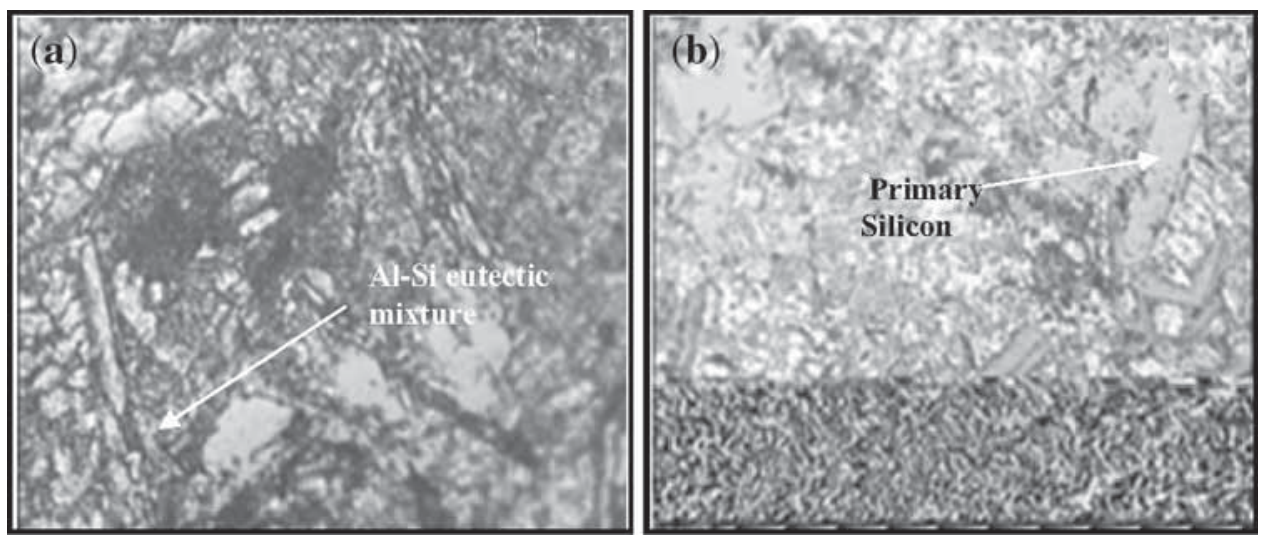

Figure 3. Microstructure of hypereutectic Al-Si alloy in different conditions: (a) as cast and (b) Cd-modified and SSM-processed $(200 \times)$.

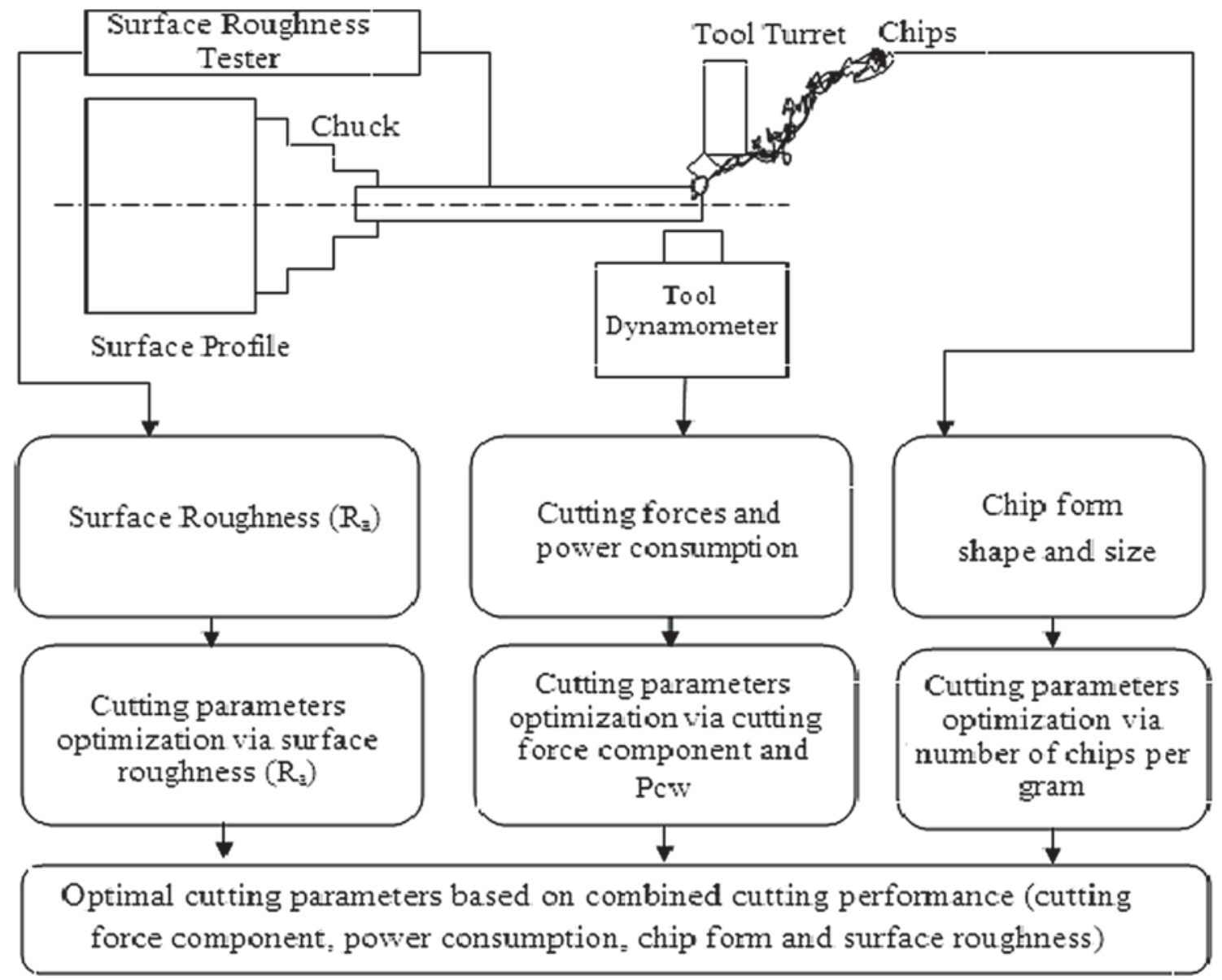

Figure 4. Schematic layout for machining parameters evaluation.

pressure is not a constant. It varies with a number of factors. The factor that affects it most is un-deformed chip thickness (7). An increase in feed rate increases the cross- section of the un-deformed chip. At the same time because of increase in chip thickness the specific cutting pressure per unit area of chip cross-section will decrease, which will 
Table 5. Experimental results for the cutting force Fc.

\begin{tabular}{|c|c|c|c|c|c|c|c|c|c|c|}
\hline \multirow{2}{*}{$\begin{array}{l}\text { Sl. } \\
\text { no. }\end{array}$} & \multirow{2}{*}{$\begin{array}{c}\mathrm{CS} \\
(\mathrm{m} / \mathrm{min})\end{array}$} & \multirow{2}{*}{$\begin{array}{l}\text { Feed rate } \\
(\mathrm{mm} / \mathrm{rev})\end{array}$} & \multirow{2}{*}{$\begin{array}{l}\text { DOC } \\
(\mathrm{mm})\end{array}$} & \multirow{2}{*}{$\begin{array}{c}\text { Approaching angle } \\
\left({ }^{\circ}\right)\end{array}$} & \multicolumn{6}{|c|}{ Cutting force $\mathrm{Fc}$} \\
\hline & & & & & Alloy 1 & Alloy 2 & Alloy 3 & Alloy 4 & Alloy 5 & Alloy 6 \\
\hline 1 & 100 & 0.1 & 1.0 & 45 & 173 & 146 & 164 & 135 & 142 & 131 \\
\hline 2 & 100 & 0.2 & 1.5 & 60 & 178 & 142 & 158 & 132 & 160 & 133 \\
\hline 3 & 100 & 0.3 & 2.0 & 75 & 183 & 170 & 165 & 153 & 167 & 141 \\
\hline 4 & 100 & 0.4 & 2.5 & 90 & 199 & 180 & 169 & 161 & 164 & 150 \\
\hline 5 & 125 & 0.1 & 1.5 & 75 & 166 & 136 & 161 & 135 & 132 & 129 \\
\hline 6 & 125 & 0.2 & 1.0 & 90 & 179 & 153 & 166 & 141 & 167 & 141 \\
\hline 7 & 125 & 0.3 & 2.5 & 45 & 188 & 176 & 166 & 160 & 164 & 158 \\
\hline 8 & 125 & 0.4 & 2.0 & 60 & 203 & 187 & 185 & 173 & 180 & 161 \\
\hline 9 & 150 & 0.1 & 2.0 & 90 & 154 & 132 & 143 & 134 & 130 & 127 \\
\hline 10 & 150 & 0.2 & 2.5 & 75 & 165 & 142 & 157 & 139 & 140 & 132 \\
\hline 11 & 150 & 0.3 & 1.0 & 60 & 176 & 154 & 163 & 148 & 156 & 145 \\
\hline 12 & 150 & 0.4 & 1.5 & 45 & 184 & 165 & 108 & 100 & 95 & 97 \\
\hline 13 & 175 & 0.1 & 2.5 & 60 & 143 & 127 & 135 & 125 & 129 & 113 \\
\hline 14 & 175 & 0.2 & 2.0 & 45 & 153 & 138 & 142 & 133 & 139 & 121 \\
\hline 15 & 175 & 0.3 & 1.5 & 90 & 161 & 154 & 153 & 146 & 145 & 129 \\
\hline 16 & 175 & 0.4 & 1.0 & 75 & 184 & 167 & 175 & 146 & 142 & 131 \\
\hline
\end{tabular}

increase the cutting force and hence feed rate increases but in not direct proportion to the increase in feed rate. Moreover, the cutting force decreases with increase in cutting speed during the machining of alloy 1-6 according to the characteristics of workpiece material and machining parameters such as cutting speed and dimensions of cut, i.e., feed rate, depth of cut and cutting force are acting on tool during machining. The tendency to develop built up edge (BUE) formation is affected by cutting speed and friction produced at chip-tool interface. The tendency of BUE formation between tool and chip is hence reduced by increasing the cutting speed, which, in turn, results in reduction of cutting force. Decreases in cutting force with increase in approaching angle have been observed for alloy 1-6. An increase in approaching angle increases the chip thickness and consequently the specific cutting pressure is reduced, which leads to reduction in cutting force.

On the basis of analysis of results, a combination of cutting parameters for minimum cutting force during machining of alloy 1-6 has been presented in table 6 . These findings were also supported by ANOVA of $S / N$ ratio.

To find the percentage contribution of different machining parameters on cutting force, which affects the performance characteristics, ANOVA was used. From the results of ANOVA, it can be observed that feed rate and depth of cut have more influence on main cutting force values than cutting speed and approaching angle for alloy 1 as the percentage contribution of the feed rate, depth of cut, cutting speed and approaching angle is 73.12, 12.86, 7.42 and $3.47 \%$, respectively. A similar trend was observed for alloy 2-6 with varying percentage contribution as shown in tables 7-12.

\subsection{Power consumption}

The secondary objective of parameter design is to optimize the setting of the process parameters values for minimizing the power consumption and to indentify the optimal process parameters. The experimental results for power consumption during the machining of hypereutectic aluminiumsilicon alloy are shown in table 13. The lower-the-better performance characteristic criterion has been considered to obtain optimal machining performance for power consumption. $S / N$ ratio and ANOVA were used to analyse the results obtained from experiments conducted for research.

On the basis of analysis of results, a combination of cutting parameters for minimum power consumption for machining of alloy 1-6 has been presented in table 14 . These findings were also supported by ANOVA of $S /$ $N$ ratio.

\subsection{Chip formation}

In this work chip form was studied with respect to average chip length and shape of the chip. Average chip length has been reported as average number of chips per gramme and shape of the chips was reported with the help of photographs of the chips captured from the conventional camera. Table 15 shows the variation in number of chips per gramme with variation in the alloy condition and machining parameters.

Number of chips per gramme decreases when the alloy is processed by semi-solid metal processing technique, and further decrease in number of chips per gramme has been noticed for the alloy modified with beryllium and cadmium 


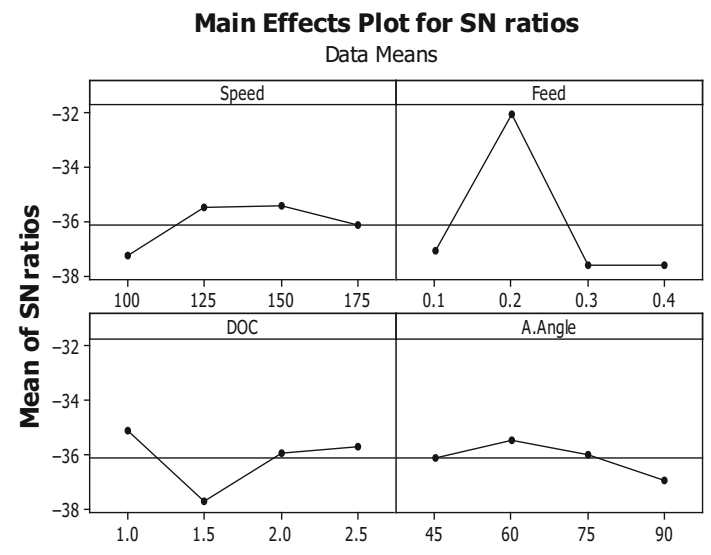

Signal-to-noise: Smaller is better

(a)

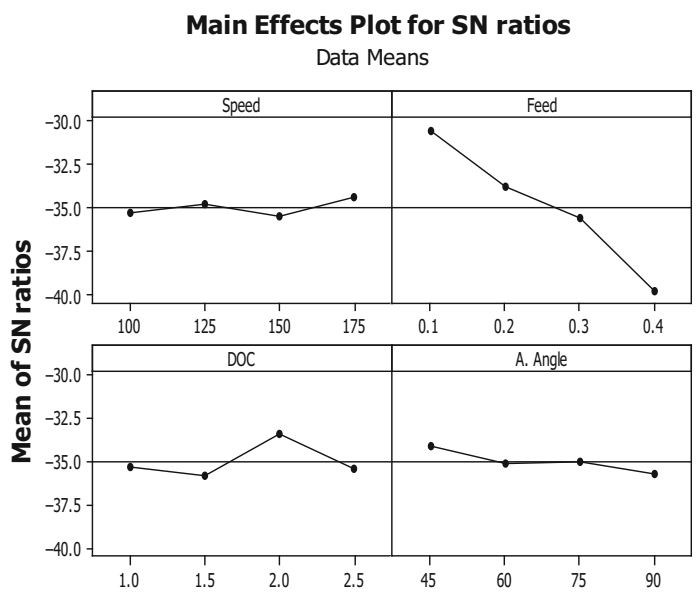

Signal-to-noise: Smaller is better

(c)

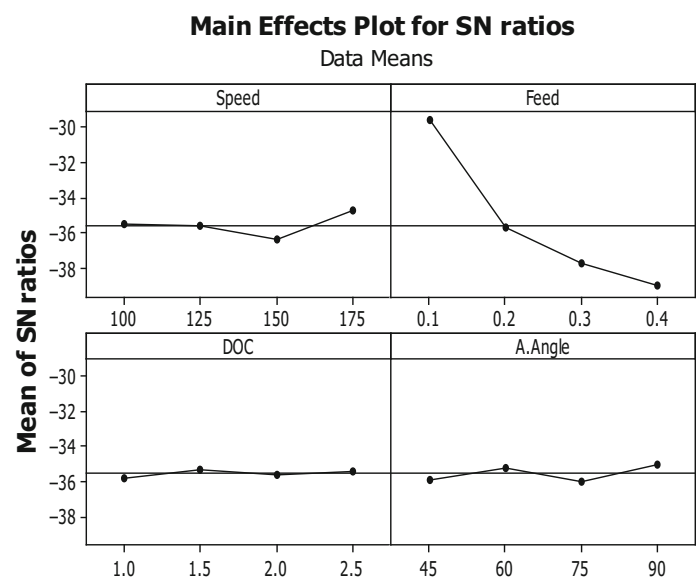

Signal-to-noise: Smaller is better

(e)

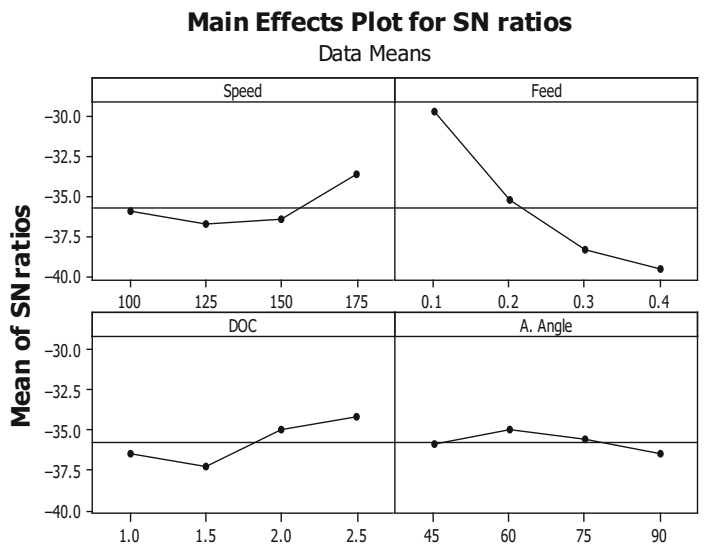

Signal-to-noise: Smaller is better

(b)

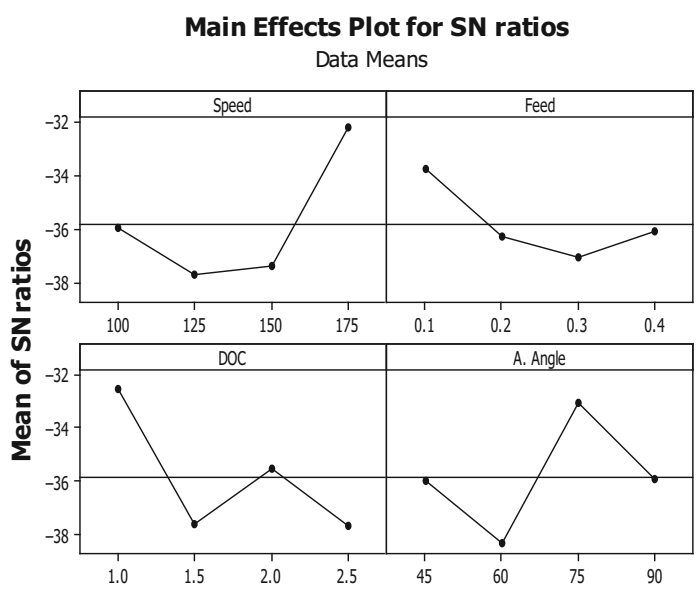

Signal-to-noise: Smaller is better

(d)

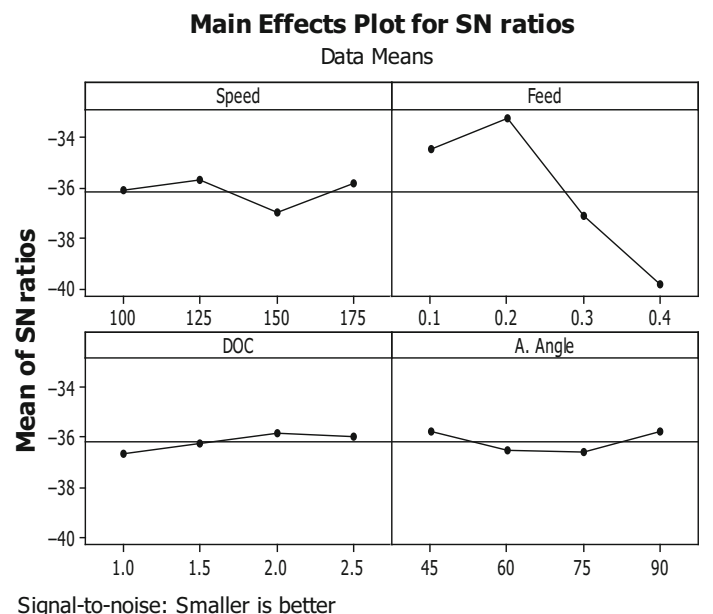

(f)

Figure 5. Effect of control factors on cutting force. (a) $\mathrm{Al}-20 \mathrm{Si}-0.5 \mathrm{Mg}-1.2 \mathrm{Fe}$ (conventional cast), (b) $\mathrm{Al}-20 \mathrm{Si}-0.5 \mathrm{Mg}-1.2 \mathrm{Fe}$ (stir cast), (c) $\mathrm{Al}-20 \mathrm{Si}-0.5 \mathrm{Mg}-1.2 \mathrm{Fe}-0.03 \mathrm{Be}$, (d) $\mathrm{Al}-20 \mathrm{Si}-0.5 \mathrm{Mg}-1.2 \mathrm{Fe}-0.03 \mathrm{Be}$ (stir cast) (conventional cast), (e) $\mathrm{Al}-20 \mathrm{Si}-0.5 \mathrm{Mg}-1.2 \mathrm{Fe}-$ $0.03 \mathrm{Cd}$ and (f) $\mathrm{Al}-20 \mathrm{Si}-0.5 \mathrm{Mg}-1.2 \mathrm{Fe}-0.03 \mathrm{Cd}$ (stir cast) (conventional cast). 
Table 6. Optimal combination of cutting parameters for cutting force Fc.

\begin{tabular}{lcccc}
\hline Alloy type & Cutting speed $(\mathrm{m} / \mathrm{min})$ & Feed rate $(\mathrm{mm} / \mathrm{rev})$ & Depth of cut $(\mathrm{mm})$ & Approaching angle $\left({ }^{\circ}\right)$ \\
\hline Alloy 1 & 150 & 0.2 & 1.0 & 60 \\
Alloy 2 & 175 & 0.1 & 2.5 & 60 \\
Alloy 3 & 175 & 0.1 & 2.0 & 45 \\
Alloy 4 & 175 & 0.1 & 1.0 & 75 \\
Alloy 5 & 175 & 0.1 & 2.5 & 90 \\
Alloy 6 & 175 & 0.2 & 2.5 & 90 \\
\hline
\end{tabular}

Table 7. ANOVA table for $\mathrm{Fc}$ of $\mathrm{Al}-20 \mathrm{Si}-0.5 \mathrm{Mg}-1.2 \mathrm{Fe}$ (conventional cast).

\begin{tabular}{lrrrrrrr}
\hline Source & DF & Seq SS & Adj SS & Adj MS & \multicolumn{1}{c}{$F$} & $P$ & Contr. $(\%)$ \\
\hline Speed & 3 & 8.87 & 8.87 & 2.95 & 2.62 & 0.225 & 7.42 \\
Feed & 3 & 87.37 & 87.37 & 29.12 & 25.80 & 0.012 \\
DOC & 3 & 15.37 & 15.37 & 5.12 & 4.54 & 0.123 & 73.12 \\
Approaching angle & 3 & 4.48 & 4.48 & 1.49 & 1.32 & 0.412 & 3.47 \\
Error & 3 & 3.38 & 3.38 & 1.12 & & 2.83 \\
Total & 15 & 119.49 & & & & 100 \\
\hline
\end{tabular}

Table 8. ANOVA table for $\mathrm{Fc}$ of $\mathrm{Al}-20 \mathrm{Si}-0.5 \mathrm{Mg}-1.2 \mathrm{Fe}$ (stir cast).

\begin{tabular}{lrrrrrrr}
\hline Source & DF & Seq SS & Adj SS & Adj MS & $F$ & $P$ & Contr. (\%) \\
\hline Speed & 3 & 23.13 & 23.13 & 7.71 & 0.81 & 0.568 & 7.41 \\
Feed & 3 & 230.31 & 230.31 & 76.77 & 8.02 & 0.061 & 74.2 \\
DOC & 3 & 23.48 & 23.48 & 7.89 & 0.82 & 0.564 & 7.59 \\
Approaching angle & 3 & 5.03 & 5.030 & 1.67 & 0.18 & 0.907 & 1.62 \\
Error & 3 & 28.72 & 28.72 & 9.57 & & 9.26 \\
Total & 15 & 310.696 & & & & 100 \\
\hline
\end{tabular}

Table 9. ANOVA table for $\mathrm{Fc}$ of $\mathrm{Al}-20 \mathrm{Si}-0.5 \mathrm{Mg}-1.2 \mathrm{Fe}-0.03 \mathrm{Be}$ (conventional cast).

\begin{tabular}{lrrrrrrr}
\hline Source & DF & Seq SS & Adj SS & Adj MS & $F$ & $P$ & Contr. (\%) \\
\hline Speed & 3 & 3.37 & 3.37 & 1.12 & 1.39 & 0.397 \\
Feed & 3 & 179.94 & 179.94 & 59.98 & 73.97 & 0.003 & 87.80 \\
DOC & 3 & 13.50 & 13.50 & 4.50 & 5.55 & 0.096 & 6.59 \\
Approaching angle & 3 & 5.66 & 5.66 & 1.88 & 2.33 & 0.253 & 2.76 \\
Error & 3 & 2.43 & 2.43 & 0.81 & & 1.34 \\
Total & 15 & 204.92 & & & & 100 \\
\hline
\end{tabular}

Table 10. ANOVA table for $\mathrm{Fc}$ of $\mathrm{Al}-20 \mathrm{Si}-0.5 \mathrm{Mg}-1.2 \mathrm{Fe}-0.03 \mathrm{Be}$ (stir cast).

\begin{tabular}{lrrrrrrr}
\hline Source & DF & Seq SS & Adj SS & Adj MS & $F$ & $P$ & Contr. (\%) \\
\hline Speed & 3 & 24.20 & 24.20 & 8.07 & 0.66 & 0.628 & 9.39 \\
Feed & 3 & 77.33 & 77.33 & 25.78 & 2.12 & 0.276 & 29.20 \\
DOC & 3 & 70.71 & 70.71 & 23.57 & 1.94 & 0.300 & 26.70 \\
Approaching angle & 3 & 56.11 & 56.11 & 18.70 & 1.54 & 0.366 & 21.12 \\
Error & 3 & 36.46 & 36.46 & 12.15 & & 13.59 \\
Total & 15 & 264.80 & & & & 100 \\
\hline
\end{tabular}


Table 11. ANOVA table for $\mathrm{Fc}$ of $\mathrm{Al}-20 \mathrm{Si}-0.5 \mathrm{Mg}-1.2 \mathrm{Fe}-0.03 \mathrm{Cd}$ (conventional cast).

\begin{tabular}{lrrrrrrr}
\hline Source & DF & Seq SS & Adj SS & Adj MS & \multicolumn{1}{c}{$F$} & $P$ & Contr. (\%) \\
\hline Speed & 3 & 5.49 & 5.49 & 1.83 & 3.93 & 0.145 & 2,52 \\
Feed & 3 & 208.13 & 208.13 & 69.37 & 149.15 & 0.001 \\
DOC & 3 & 0.43 & 0.43 & 0.14 & 0.31 & 0.820 & 0.19 \\
Approaching angle & 3 & 2.54 & 2.54 & 0.84 & 1.82 & 0.317 & 1.16 \\
Error & 3 & 1.39 & 1.39 & 0.46 & & 0.69 \\
Total & 15 & 217.99 & & & & 100 \\
\hline
\end{tabular}

Table 12. ANOVA table for $\mathrm{Fc}$ of $\mathrm{Al}-20 \mathrm{Si}-0.5 \mathrm{Mg}-1.2 \mathrm{Fe}-0.03 \mathrm{Cd}$ (stir cast).

\begin{tabular}{lrrrrrrr}
\hline Source & DF & Seq SS & Adj SS & Adj MS & $F$ & $P$ & Contr. (\%) \\
\hline Speed & 3 & 4.14 & 4.14 & 1.38 & 0,89 & 0.536 & 3.57 \\
Feed & 3 & 103.39 & 103.39 & 34.46 & 22.30 & 0.015 & 89.02 \\
DOC & 3 & 1.53 & 1.53 & 0.51 & 0.33 & 0.806 & 1.32 \\
Approaching angle & 3 & 4.24 & 4.24 & 0.80 & 0.52 & 0.696 & 2.08 \\
Error & 3 & 4.63 & 4.63 & 1.54 & & 4.01 \\
Total & 15 & 116.141 & & & & 100 \\
\hline
\end{tabular}

Table 13. Experimental results for power consumption.

Power consumption Pcw

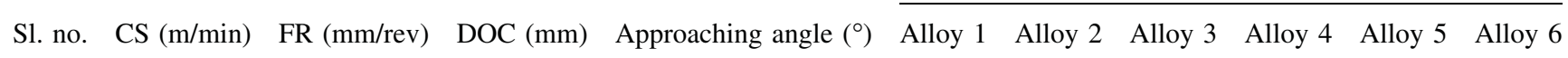

\begin{tabular}{|c|c|c|c|c|c|c|c|c|c|c|}
\hline 1 & 100 & 0.1 & 1.0 & 45 & 112 & 76 & 67 & 58 & 64 & 49 \\
\hline 2 & 100 & 0.2 & 1.5 & 60 & 105 & 81 & 76 & 64 & 69 & 58 \\
\hline 3 & 100 & 0.3 & 2.0 & 75 & 137 & 118 & 90 & 89 & 83 & 65 \\
\hline 4 & 100 & 0.4 & 2.5 & 90 & 165 & 133 & 121 & 105 & 99 & 81 \\
\hline 5 & 125 & 0.1 & 1.5 & 75 & 107 & 66 & 60 & 42 & 58 & 39 \\
\hline 6 & 125 & 0.2 & 1.0 & 90 & 110 & 70 & 77 & 54 & 61 & 46 \\
\hline 7 & 125 & 0.3 & 2.5 & 45 & 130 & 108 & 85 & 79 & 73 & 47 \\
\hline 8 & 125 & 0.4 & 2.0 & 60 & 145 & 130 & 117 & 104 & 81 & 71 \\
\hline 9 & 150 & 0.1 & 2.0 & 90 & 105 & 63 & 55 & 40 & 53 & 36 \\
\hline 10 & 150 & 0.2 & 2.5 & 75 & 109 & 69 & 59 & 41 & 55 & 38 \\
\hline 11 & 150 & 0.3 & 1.0 & 60 & 127 & 97 & 78 & 68 & 67 & 39 \\
\hline 12 & 150 & 0.4 & 1.5 & 45 & 160 & 106 & 78 & 71 & 70 & 43 \\
\hline 13 & 175 & 0.1 & 2.5 & 60 & 99 & 60 & 54 & 38 & 50 & 30 \\
\hline 14 & 175 & 0.2 & 2.0 & 45 & 104 & 64 & 59 & 40 & 57 & 40 \\
\hline 15 & 175 & 0.3 & 1.5 & 90 & 121 & 75 & 69 & 52 & 71 & 51 \\
\hline 16 & 175 & 0.4 & 1.0 & 75 & 175 & 129 & 79 & 63 & 77 & 64 \\
\hline
\end{tabular}

addition. The chip form (shape) depends upon the cutting conditions, method of alloy developed as well as modification of alloy.

Different types of chips were formed during turning of $\mathrm{Al}-20 \mathrm{Si}-0.5 \mathrm{Mg}-1.2 \mathrm{Fe}$ alloys under different conditions. It can be observed from table 16 that almost all types of chip shapes such as continuous saw toothed, semi-continuous saw toothed, long helical, broken helical, needle chips and snary chips are produced during the machining of hypereutectic alloy under different cutting conditions of alloys and methods of processing. An increase in cutting speed transforms the chip from snary helical to broken helical during the machining of hypereutectic alloy when the alloy is processed by semi-solid metal processing technique with the addition of $\mathrm{Be} / \mathrm{Cd}$. This is the desired chip form from machinability point of view. Due to reduction in friction at tool-chip interface the form of chip changes with increasing cutting speed. Figure $6 \mathrm{a}$ and $\mathrm{b}$ shows the SEM images of saw tooth chips obtained at $150 \mathrm{~m} / \mathrm{min}$ cutting speed, $0.1 \mathrm{~mm} / \mathrm{rev}$ feed rate, $2.0 \mathrm{~mm}$ depth of cut and $45^{\circ}$ approaching angle generated during the machining of $\mathrm{Al}-$ $20 \mathrm{Si}-0.05 \mathrm{Mg}-1.2 \mathrm{Fe}$ alloy processed by conventional cast 
Table 14. Optimal combination of cutting parameters for power consumption.

\begin{tabular}{lcccc}
\hline Alloy type & Cutting speed $(\mathrm{m} / \mathrm{min})$ & Feed rate $(\mathrm{mm} / \mathrm{rev})$ & Depth of cut $(\mathrm{mm})$ & Approaching angle $\left(^{\circ}\right)$ \\
\hline Alloy 1 & 100 & 0.2 & 1.0 & 75 \\
Alloy 2 & 100 & 0.1 & 2.5 & 60 \\
Alloy 3 & 100 & 0.1 & 2.0 & 45 \\
Alloy 4 & 100 & 0.1 & 1.0 & 75 \\
Alloy 5 & 100 & 0.1 & 2.5 & 90 \\
Alloy 6 & 100 & 0.2 & 2.5 & 90 \\
\hline
\end{tabular}

Table 15. Chip thickness ratio for hypereutectic Al-Si alloys.

\begin{tabular}{|c|c|c|c|c|c|c|c|c|c|c|}
\hline $\begin{array}{l}\text { S1. } \\
\text { no. }\end{array}$ & $\begin{array}{l}\mathrm{CS}(\mathrm{m} / \\
\min )\end{array}$ & $\begin{array}{c}\text { Feed rate }(\mathrm{mm} / \\
\text { rev })\end{array}$ & $\begin{array}{l}\mathrm{DOC} \\
(\mathrm{mm})\end{array}$ & $\begin{array}{c}\text { Approaching angle } \\
\left({ }^{\circ}\right)\end{array}$ & $\begin{array}{c}\text { Alloy } \\
1\end{array}$ & $\begin{array}{l}\text { Alloy } \\
2\end{array}$ & $\begin{array}{c}\text { Alloy } \\
3\end{array}$ & $\begin{array}{c}\text { Alloy } \\
4\end{array}$ & $\begin{array}{c}\text { Alloy } \\
5\end{array}$ & $\begin{array}{c}\text { Alloy } \\
6\end{array}$ \\
\hline 1 & 100 & 0.1 & 1.0 & 45 & 810 & 432 & 635 & 360 & 576 & 235 \\
\hline 2 & 100 & 0.2 & 1.5 & 60 & 825 & 440 & 654 & 375 & 590 & 240 \\
\hline 3 & 100 & 0.3 & 2.0 & 75 & 836 & 471 & 650 & 390 & 590 & 290 \\
\hline 4 & 100 & 0.4 & 2.5 & 90 & 840 & 479 & 671 & 404 & 605 & 320 \\
\hline 5 & 125 & 0.1 & 1.5 & 75 & 760 & 413 & 608 & 346 & 436 & 232 \\
\hline 6 & 125 & 0.2 & 1.0 & 90 & 777 & 419 & 611 & 359 & 453 & 260 \\
\hline 7 & 125 & 0.3 & 2.5 & 45 & 780 & 450 & 643 & 372 & 450 & 282 \\
\hline 8 & 125 & 0.4 & 2.0 & 60 & 794 & 467 & 657 & 380 & 465 & 290 \\
\hline 9 & 150 & 0.1 & 2.0 & 90 & 666 & 367 & 549 & 346 & 406 & 229 \\
\hline 10 & 150 & 0.2 & 2.5 & 75 & 683 & 375 & 550 & 386 & 414 & 245 \\
\hline 11 & 150 & 0.3 & 1.0 & 60 & 689 & 390 & 562 & 399 & 440 & 263 \\
\hline 12 & 150 & 0.4 & 1.5 & 45 & 730 & 413 & 568 & 417 & 464 & 283 \\
\hline 13 & 175 & 0.1 & 2.5 & 60 & 534 & 419 & 423 & 328 & 410 & 188 \\
\hline 14 & 175 & 0.2 & 2.0 & 45 & 556 & 376 & 448 & 363 & 434 & 205 \\
\hline 15 & 175 & 0.3 & 1.5 & 90 & 575 & 449 & 467 & 389 & 465 & 228 \\
\hline 16 & 175 & 0.4 & 1.0 & 75 & 610 & 567 & 477 & 417 & 469 & 232 \\
\hline
\end{tabular}

and semi-solid metal processing techniques. The cast alloy primarily produces broken saw tooth chips, while the semisolid metal processing alloy results in uniform saw tooth profile. These results show that the chip formation during the machining of hypoeutectic alloy is influenced by cutting parameters, method of processing and mechanical properties.

\subsection{Surface roughness}

To investigate the effect of machining parameters on surface roughness of $\mathrm{Al}-\mathrm{Si}-\mathrm{Mg}$ hypereutectic alloys using orthogonal array $\mathrm{L}_{16}$ of Taguchi approach, experimentation was conducted. Lower-the-better approach has been considered for indentifying the optimized parameter for surface roughness. Table 17 shows the experimental results obtained for surface roughness of alloys reported as per design matrix. On the basis of analysis of results, a combination of cutting parameters for minimum surface roughness during machining of alloy 1-6 has been presented in table 18. These findings were also supported by ANOVA of $S / N$ ratio.

It was observed that semi-solid metal processing of $\mathrm{Cd} /$ Be-modified alloy reduces the surface roughness compared with the conventional technique as evident from the SEM images of machined surface (figure 7). The probable reason for this is increase in hardness of material and grain structure refinement as hard material gives better surface finish than soft material owing to lesser tendency for BUE formation. The abrasive action by the silicon particles produces the flank wear of the insert as shown in the SEM images of the insert (figure 8). Under the same conditions, with increase in feed rate the surface roughness increases. Surface finish is primarily affected by feed marks, BUE and vibration. Hence, dimensions of cut would influence the surface finish to the extent they influence the feed ridge, BUE and vibrations. The height of feed ridge is influenced by feed rate. Increase in feed rate increases the BUE formation tendency, which in turn leads to higher surface roughness. 
Table 16. Chip shape under different machining conditions for hypereutectic alloys.

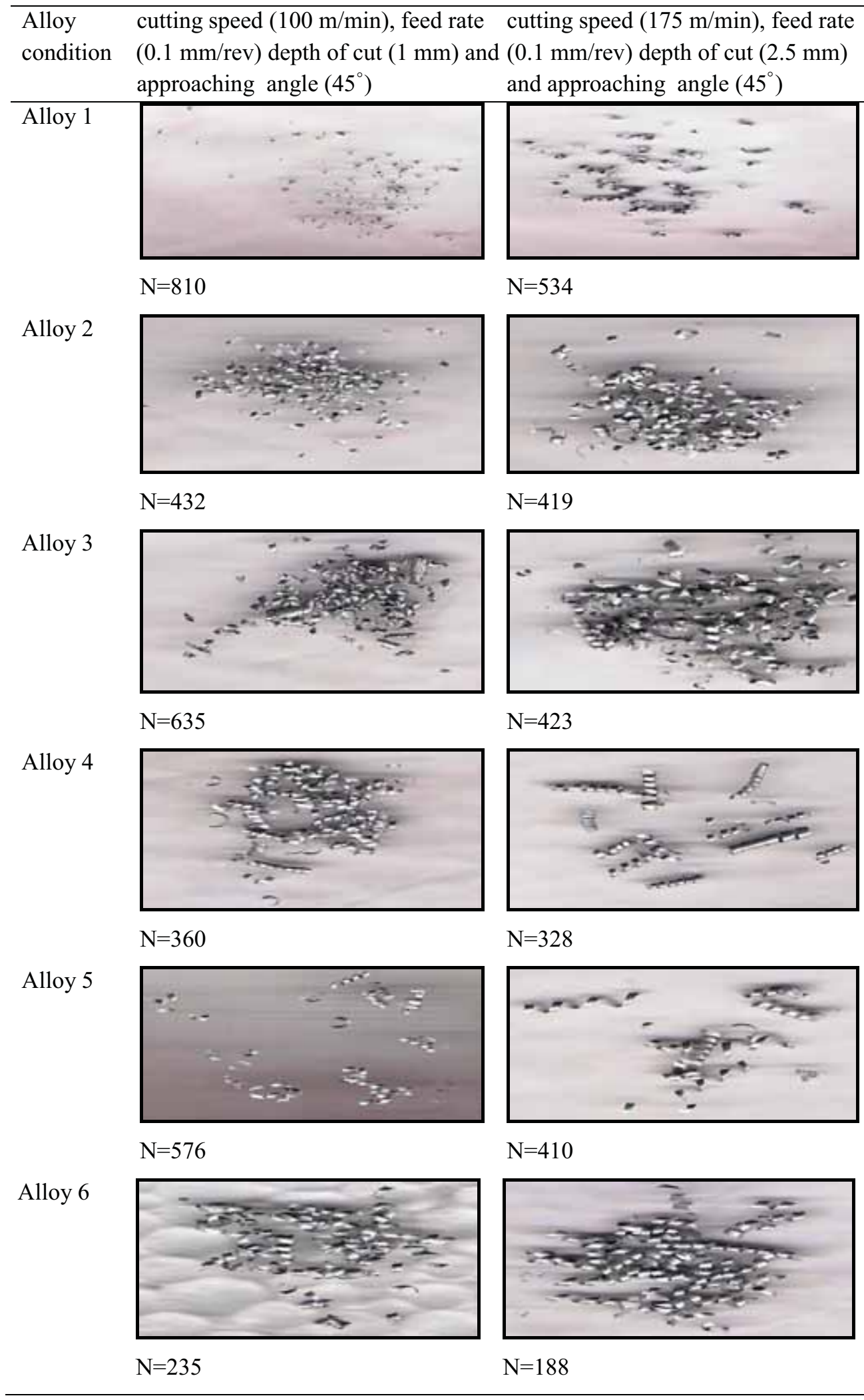




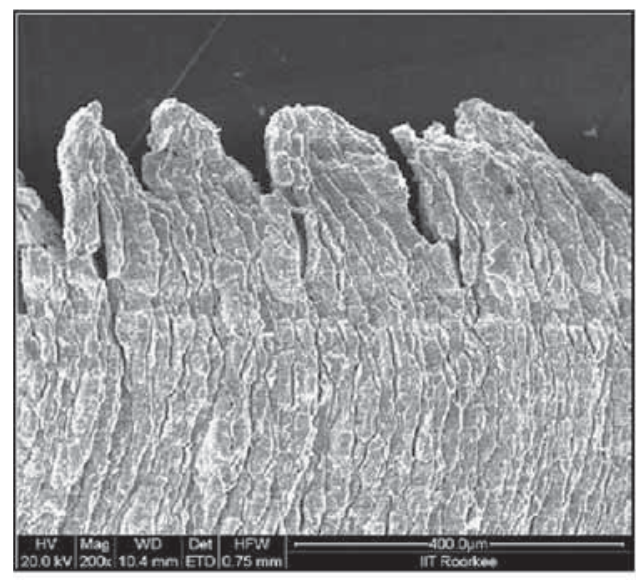

(a)

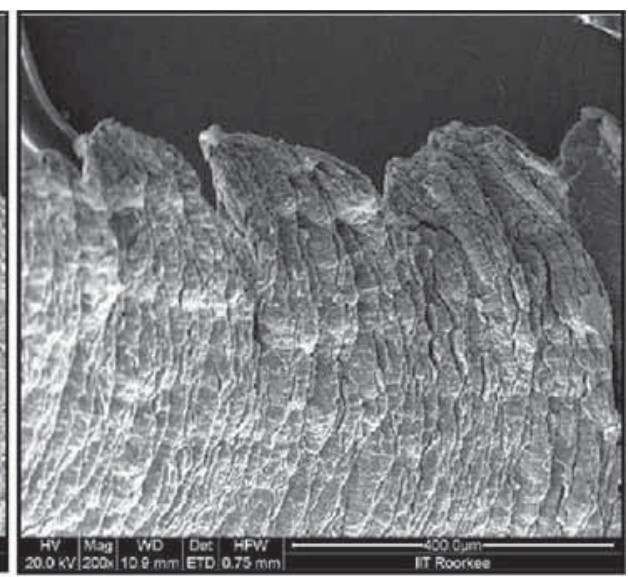

(b)

Figure 6. SEM image of a saw-toothed chip at $150 \mathrm{~m} / \mathrm{min}$ cutting speed, $0.1 \mathrm{~mm} / \mathrm{rev}$ feed rate, $2.0 \mathrm{~mm}$ depth of cut and $45^{\circ}$ approaching angle. (a) Al-20Si-0.5Mg-1.2Fe (conventional cast) and (b) Al-20Si-0.5Mg-1.2Fe (semi-solid metal processing).

Table 17. Experimental results for surface roughness.

\begin{tabular}{|c|c|c|c|c|c|c|c|c|c|c|}
\hline \multirow[b]{2}{*}{$\begin{array}{l}\text { Sl. } \\
\text { no. }\end{array}$} & \multirow[b]{2}{*}{$\begin{array}{c}\mathrm{CS}(\mathrm{m} / \\
\min )\end{array}$} & \multirow[b]{2}{*}{$\begin{array}{c}\text { Feed rate }(\mathrm{mm} / \\
\text { rev })\end{array}$} & \multirow[b]{2}{*}{$\begin{array}{l}\text { DOC } \\
(\mathrm{mm})\end{array}$} & \multirow[b]{2}{*}{$\begin{array}{c}\text { Approaching angle } \\
\left({ }^{\circ}\right)\end{array}$} & \multicolumn{6}{|c|}{ Surface roughness $R_{\mathrm{a}}$} \\
\hline & & & & & $\begin{array}{c}\text { Alloy } \\
1\end{array}$ & $\begin{array}{l}\text { Alloy } \\
2\end{array}$ & $\begin{array}{c}\text { Alloy } \\
3\end{array}$ & $\begin{array}{c}\text { Alloy } \\
4\end{array}$ & $\begin{array}{l}\text { Alloy } \\
5\end{array}$ & $\begin{array}{c}\text { Alloy } \\
6\end{array}$ \\
\hline 1 & 100 & 0.1 & 1.0 & 45 & 5.58 & 4.15 & 4.75 & 4.67 & 3.88 & 3.78 \\
\hline 2 & 100 & 0.2 & 1.5 & 60 & 4.07 & 4.37 & 5.16 & 5.14 & 6.60 & 3.47 \\
\hline 3 & 100 & 0.3 & 2.0 & 75 & 4.66 & 6.26 & 4.40 & 4.33 & 8.34 & 3.56 \\
\hline 4 & 100 & 0.4 & 2.5 & 90 & 7.46 & 6.67 & 7.04 & 4.42 & 6.43 & 4.18 \\
\hline 5 & 125 & 0.1 & 1.5 & 75 & 5.96 & 3.65 & 4.64 & 5.87 & 3.78 & 2.91 \\
\hline 6 & 125 & 0.2 & 1.0 & 90 & 3.24 & 5.21 & 4.41 & 4.40 & 6.55 & 3.19 \\
\hline 7 & 125 & 0.3 & 2.5 & 45 & 4.17 & 3.9 & 5.98 & 6.68 & 7.08 & 5.12 \\
\hline 8 & 125 & 0.4 & 2.0 & 60 & 4.12 & 3.90 & 7.61 & 3.59 & 3.75 & 5.87 \\
\hline 9 & 150 & 0.1 & 2.0 & 90 & 4.01 & 2.33 & 4.04 & 4.41 & 3.25 & 3.96 \\
\hline 10 & 150 & 0.2 & 2.5 & 75 & 2.14 & 2.00 & 4.88 & 3.50 & 6.92 & 3.68 \\
\hline 11 & 150 & 0.3 & 1.0 & 60 & 5.40 & 3.08 & 5.82 & 5.29 & 5.23 & 4.80 \\
\hline 12 & 150 & 0.4 & 1.5 & 45 & 3.05 & 2.66 & 6.71 & 5.30 & 3.61 & 3.74 \\
\hline 13 & 175 & 0.1 & 2.5 & 60 & 5.12 & 3.34 & 3.95 & 4.57 & 2.48 & 3.40 \\
\hline 14 & 175 & 0.2 & 2.0 & 45 & 4.26 & 3.59 & 4.45 & 3.18 & 4.80 & 3.63 \\
\hline 15 & 175 & 0.3 & 1.5 & 90 & 5.40 & 4.14 & 6.10 & 3.94 & 5.45 & 3.98 \\
\hline 16 & 175 & 0.4 & 1.0 & 75 & 7.87 & 5.59 & 6.76 & 6.10 & 3.52 & 4.06 \\
\hline
\end{tabular}

\section{Conclusions}

The major conclusions of the study are as follows:

- Feed rate is the only significant factor that influences the machining characteristics such as cutting forces, power consumption, chip thickness ratio chip and surface roughness in all the stages of alloy developed by conventional casting and semi-solid metal processing technique with the addition of iron corrector (Be and $\mathrm{Cd}$ ) due to refinement and modification of microconstituents.
- The addition of cadmium, i.e., $\mathrm{Al}-20 \mathrm{Si}-0.5 \mathrm{Mg}-$ $1.2 \mathrm{Fe}-0.03 \mathrm{Cd}$ and semi-solid metal processing result in lower cutting force component, power consumption and surface roughness because of improved homogeneity of elements. The main reason is that $\mathrm{Cd}$ is used to reduce the oxidation at elevated temperatures; addition of $\mathrm{Cd}$ changes the morphology of iron-containing particles and almost eliminates the harmful $\beta$ phase needle shape intermetallic compounds from microstructure, thus improving the machinability. 
Table 18. Optimal combination of cutting parameters for surface roughness.

\begin{tabular}{lcccc}
\hline Alloy type & Cutting speed $(\mathrm{m} / \mathrm{min})$ & Feed rate $(\mathrm{mm} / \mathrm{rev})$ & Depth of cut $(\mathrm{mm})$ & Approaching angle $\left(^{\circ}\right)$ \\
\hline Alloy 1 & 150 & 0.3 & 1.5 & 45 \\
Alloy 2 & 150 & 0.2 & 2.0 & 45 \\
Alloy 3 & 175 & 0.4 & 2.0 & 60 \\
Alloy 4 & 175 & 0.4 & 1.0 & 75 \\
Alloy 5 & 175 & 0.1 & 1.0 & 45 \\
Alloy 6 & 175 & 0.4 & 60 \\
\hline
\end{tabular}
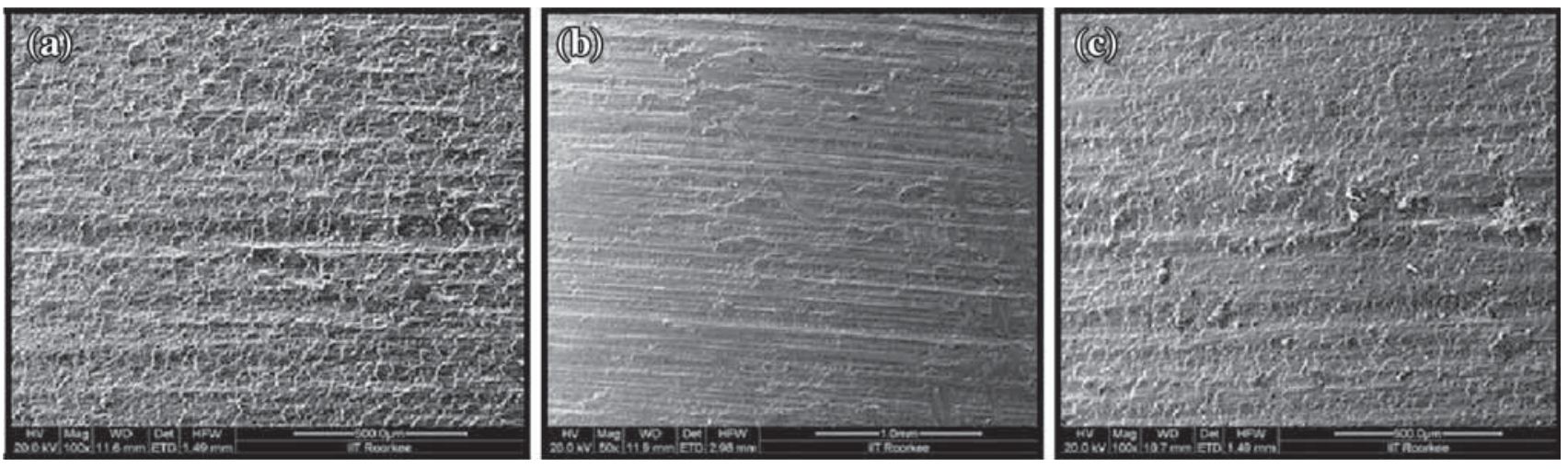

Figure 7. SEM image of machined surface: (a) Al-20Si-0.5Mg-1.2Fe (stir cast), at cutting speed $150 \mathrm{~m} / \mathrm{min}$, feed rate $0.3 \mathrm{~mm} / \mathrm{rev}$, depth of cut $1.5 \mathrm{~mm}$ and approaching angle $75^{\circ}$, (b) $\mathrm{Al}-20 \mathrm{Si}-0.5 \mathrm{Mg}-1.2 \mathrm{Fe}-0.03 \mathrm{Be}$ (conventional) at cutting speed of $175 \mathrm{~m} / \mathrm{min}$, feed rate $0.1 \mathrm{~mm} / \mathrm{rev}$, depth of cut $1.0 \mathrm{~mm}$ and approaching angle $\left(75^{\circ}\right)$ and (c) $\mathrm{Al}-20 \mathrm{Si}-0.5 \mathrm{Mg}-1.2 \mathrm{Fe}-0.03 \mathrm{Be}$ (stirring), at cutting speed of $175 \mathrm{~m} / \mathrm{min}$ ), feed rate $0.4 \mathrm{~mm} / \mathrm{rev}$, depth of cut $1.5 \mathrm{~mm}$ and approaching angle $75^{\circ}$.
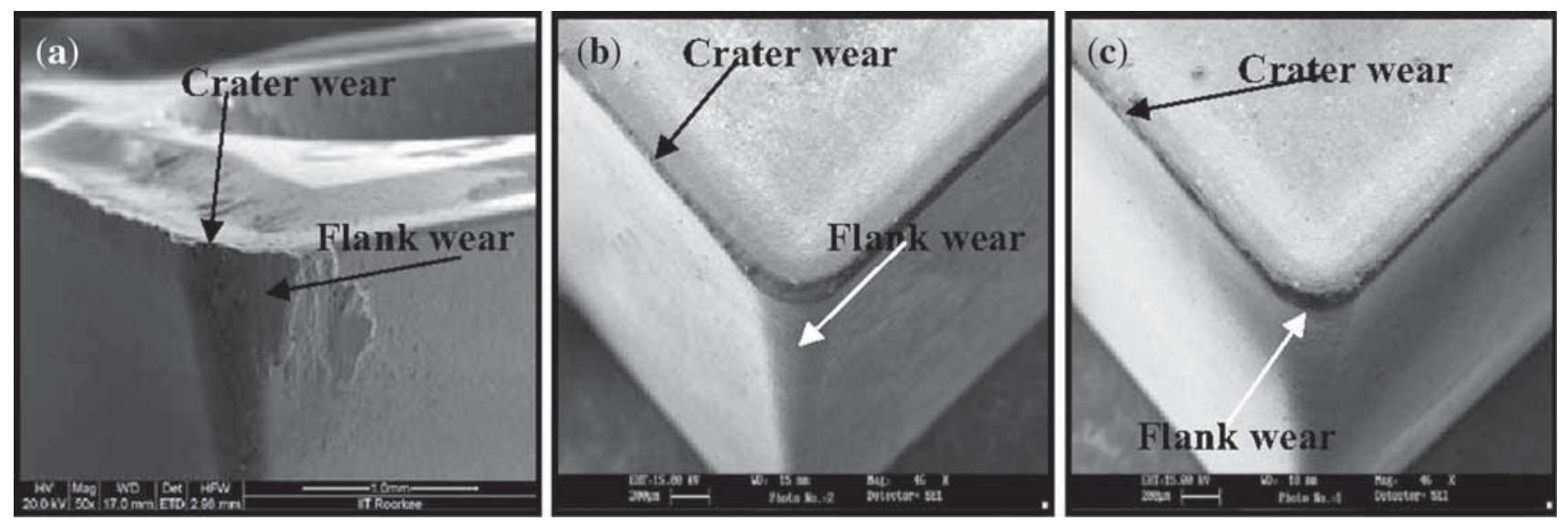

Figure 8. SEM image of tool wear (crater wear on rake face and flank wear on flank surface): (a) Al-20Si-0.5Mg-1.2Fe (stir cast), at cutting speed $150 \mathrm{~m} / \mathrm{min}$, feed rate $0.3 \mathrm{~mm} / \mathrm{rev}$, depth of cut $1.5 \mathrm{~mm}$ and approaching angle $75^{\circ},(\mathbf{b}) \mathrm{Al}-20 \mathrm{Si}-0.5 \mathrm{Mg}-1.2 \mathrm{Fe}-0.03 \mathrm{Be}$ (conventional) at cutting speed of $175 \mathrm{~m} / \mathrm{min}$, feed rate $0.1 \mathrm{~mm} / \mathrm{rev}$, depth of cut $1.0 \mathrm{~mm}$ and approaching angle $\left(75^{\circ}\right)$ and $(\mathbf{c}) \mathrm{Al}-20 \mathrm{Si}-$ $0.5 \mathrm{Mg}-1.2 \mathrm{Fe}-0.03 \mathrm{Be}$ (stirring) at cutting speed of $175 \mathrm{~m} / \mathrm{min}$, feed rate $0.4 \mathrm{~mm} / \mathrm{rev}$, depth of cut $1.5 \mathrm{~mm}$ and approaching angle $75^{\circ}$.

- The chip form is of helical type and number of chips per gramme also decreases when the base alloy is processed with semi-solid metal processing technique with the addition of iron correctors.
- $\mathrm{Cd}$ as iron corrector is more effective as compared with Be for improving the machinability of hypoeutectic aluminium-silicon alloy. 


\section{Acknowledgment}

The authors gratefully acknowledge the NIT authorities for granting the permission to avail the facilities and financial support in order to complete this research work. The authors also acknowledge the technical support provided by the staff of Central Workshop and Mechanical Engineering Department, NIT, Hamirpur, and I.I.T. Roorkee during preparation and testing of the alloys.

\section{References}

[1] Lee E S 2000 A study on the economics of hypereutectic aluminium-silicon alloy machining. J. Adv. Manuf. Technol. 16: 700-708

[2] Ryou M, Kim C H and Kim M H 2008 Microstructure and mechanical properties of hyper-eutectic Al-Si alloys fabricated by spray casting. J. Mater. Sci. Technol. 24(I): 48-50

[3] Tanka T and Akasawa T 1999 Machinability of hypereutectic silicon-aluminium alloy. J. Mater. Eng. Perform. 8: 463-468

[4] Halla N F, Secordel P and Suery M 1998 Microstructure and mechanical properties of modified and non-modified stir cast Al-Si alloy. J. Mater. Sci. 23: 2419-2423

[5] Karal M V, Nakashima P N H and Mitchell D R G 2006 Electro-microscope studies of Al-Fe-Si intermetallics in an Al-11 pCt Si alloy. J. Mater. Process. Technol. 200: 373-384

[6] Reddy B S, Padmanabhan G and Reddy V K 2008 Surface roughness prediction techniques for CNC turning. Asian J. Sci. Res. 1(3): 256-264

[7] Dwivedi D K, Sharma A and Rajan T V 2008 Machining of LM13 and LM28 cast aluminum alloys: part - I. J. Mater. Process. Technol. 196: 197-204
[8] Trent E M and Wright P K 2006 Forces and stresses in metal cutting. In: Metal cutting, USA: Butterworth-Heinemann, pp. $57-95$

[9] Sharma V S, Dhiman S, Sehgal R and Kumar S 2008 Assessment and optimization of cutting parameters while turning AlSI 52100 steel. Int. J. Precis. Eng. Manuf. 9: 54-62

[10] Aggarwal A, Singh H, Kumar P and Singh M 2008 Optimizing power consumption for $\mathrm{CNC}$ turned parts using response surface methodology and Taguchi's technique - a comparative analysis. J. Mater. Process. Technol. 200: 373-384

[11] Mahapatra S S, Patnaik A and Patnaik P K 2006 Parametric analysis and optimization of cutting parameters for turning operations based on Taguchi method. In: Proceedings of the International Conference on Global Manufacturing and Innovation, pp. 1-8

[12] Sood P K, Sehgal R and Dwivedi D K 2009 Study on chip formation in machining (Al-Si-1.2Fe) hypereutectic aluminium alloy. In: Proceedings of the National Conference on Design and Manufacturing Issues in Automobile and Allied Industry, IITM, Chennai, pp. 16-22

[13] Nalbant M, Gokkaya H and Sur G 2007 Application of Taguchi method in the optimization of cutting parameters for surface roughness in turning. J. Mater. Des. 28(4): 1379-1385

[14] Nain C V, Yang W H and Tarng Y S 1999 Optimization of turning operations with multiple performance characteristics. J. Mater. Process. Technol. 95: 90-96

[15] Rodrígueza S H, Rafael E, Reyesa G, Dwivedi D K, Gonzáleza O A and Hernández V H B 2012 The effect of Al5Ti-1B on microstructure and mechanical properties of $\mathrm{Al}-$ 12Si-xFe alloy. Mater. Manuf. Process. 27(6): 599-604

[16] Ellis M B D 1996 Joining of Al-based metal matrix composites - a review. Mater. Manuf. Process. 11(1): 45-66

[17] Keipke R, Buchkremer-Hermanns H, WeiB H and Ren H 1998 Machining of hypereutectic Al-Si alloy with CVD diamond coated $\mathrm{Si}_{4} \mathrm{~N}_{4}$ inserts. Mater. Manuf. Process. 13(4): 603-610 